\title{
PENGARUH PENYAJIAN LAPORAN KEUANGAN DAERAH, AKSESIBILITAS LAPORAN KEUANGAN DAN AKUNTABILITAS PENGELOLAAN KEUANGAN DAERAH TERHADAP PENGGUNAAN INFORMASI KEUANGAN DARAH (STUDI KASUS PADA KABUPATEN ACEH UTARA)
}

\author{
Dy Ilham Satria ${ }^{1}$, Muhammad Ahwal Bobby ${ }^{2}$ \\ ${ }^{1,2}$ Prodi Akuntansi Fakultas Ekonomi dan Bisnis Universitas Malikussaleh Lhokseumawe \\ dyilham@unimal.ac.id
}

\begin{abstract}
This research aims to empirically examine whether the presentation of local financial reports, accessibility of financial report and accountability of local financial management of local finacial information by the stakeholders.this research was carried out in Aceh Utara local residence using method to collect data through survey questionnaire. They were given for the stakeholder as a user of local financial information which respondents were the member of local legislative and the local Apparatures Working Units (SKPK). By the purposive sampling method, fixed get sample from 5 members of local legislative and 68 members of local Apparatures Working Units. The test and analysis use double linear regression after the reliability test, validity test andcalssical assumption test were done. The result of test showed that the presentation of local financial reports, accessibility of financial reports and accountability of local financial management understanding significant affect to the use of local financial information.
\end{abstract}

Keywords: Local Financial Report, accessibility, accountability of local financial Management, Local Financial Information.

\section{PENDAHULUAN}

Seiring berkembangnya sektor publik yang terjadi di Indonesia akhir-akhir ini adalah mengenai fenomena kuatnya tuntutan penggunaan informasi keuangan atas lembaga-lembaga publik, baik di pemerintah pusat maupun di pemerintah daerah. Tuntutan tersebut perlu dilakukannya sebuah transparansi kepada publik serta pemerintah juga perlu melakukan pemberian informasi kepada publik yang didasarkan atas pemenuhan hak-hak publik. Kurangnya pemerintah dalam memberikan informasi keuangan untuk saat ini menyebabkan pertanggungjawaban pemerintah daerah berupa laporan keuangan belum sepenuhnya mempunyai akses yang memudahkan masyarakat dalam mendapatkan informasi keuangan daerah. Hal ini disebabkan karena laporan tahunan yang tidak memuat semua informasi yang relevan yang dibutuhakn oleh para pengguna laporan keuangan, sehingga laporan keuangan tersebut bersifat tidak aksesibel dan kurang lengkap tersebut secara mudah dapat menurunkan kualitas dari akuntabilitas keuangan daerah.

Menurut Sanjaya, dkk (2014) penggunaan informasi laporan keuangan daerah berkaitan dengan penilaian para pengguna laporan keuangan daerah terhadap akuntabilitas dan transparansi setiap laporan keuangan yang disajikan oleh pemerintah. Untuk memuaskan pengguna informasi keuangan, sangat perlu dilakukan upaya untuk menggali apa saja informasi-informasi yang dibutuhkan oleh pengguna laporan keuangan daerah.

Dalam hal ini, fenomena yang terjadi pada Kabupaten Aceh Utara adalah Pemerintah Daerah belum sepenuhnya memberikan informasi keuangan yang akuntabel, hal ini dikarenakan oleh beberapa fenomena akuntabilitas yang terjadi, diantaranya berdasarkan data yang dikutip dari BPK RI Perwakilan Aceh bahwa laporan keuangan pada tahun 2014 menunjukkan masih terdapatnya kelamahan-kelemahan pada sistem pengendalian intern dan ketidaksesuaian terhadap perundangundangan. Pada tahun 2016 BPK juga 
mendapatkan beberapa permasalahan yaitu, penatausahaan aset tetap belum memadai, pengelolaan investasi nonpermanent-dana bergilir belum memadai dan kesalahan dalam penganggaran pada tujuh SKPK senilai Rp.24,14 milyar.

Berdasarkan uraian latar belakang yang dikemukakan diatas, maka dapat dirumuskan suatu rumusan masalah yaitu apakah penyajian laporan keuangan daerah, aksesibilitas laporan keuangan dan akuntablitas pengelolaan keuangan daerah terhadap penggunaan informasi keuangan daerah pada Kabupaten Aceh Utara. Penelitian ini bertujuan untuk menguji pengaruh penyajian laporan keuangan, aksesibilitas laporan keuangan dan akuntabilitas pengelolaan keuangan daerah terhadap penggunaan informasi keuangan daerah pada Kabupaten Aceh Utara.

\section{TINJAUAN PUSTAKA}

\section{Penggunaan Informasi Keuangan Daerah (Y)}

Pembuatan laporan keuangan daerah bertujuan untuk memberi informasi keuangan yang berguna untuk pembuatan keputusan ekonomi, sosial, politik dan juga laporan akuntabilitas itu sendiri. Selain tujuan tersebut, tujuan yang lebih penting dalam pelaporan itu adalah kepuasan pengguna informasi (Ramadhani, 2014). Menurut Saputra (2012) Penggunaan informasi keuangan daerah berkaitan dengan penilaian para pengguna laporan keuangan daerah terhadap akuntabilitas dan transparansi setiap laporan keuangan yang disajikan oleh pemerintah daerah.

Terdapat beberapa kelompok utama pengguna laporan keuangan pemerintah dalam pernyataan PSAP No. 1 alinea 36 (PP No. 71 tahun 2010), meliputi :

1. Masyarakat

2. Para wakil rakyat dan lembaga pengawas dan lembaga pemeriksa

3. Pihak yang memberi atau berperan dalam proses donasi, investasi dan pinjaman

4. Pemerintah

\section{Penyajian Laporan Keuangan Daerah $\left(\mathbf{X}_{1}\right)$}

Dalam pernyataan PP Nomor 71 Tahun 2010 tentang Standar Akuntansi Pemerintah bahwa laporan keuangan merupakan laporan yang berstruktur mengenai posisi keuangan dan transaksi-transaksi yang dilakukan oleh suatu entitas pelaporan.
Laporan keuangan sektor publik merupakan representasi terstruktur posisi keuangan akibat transaksi yang dilakukan. Laporan keuangan organisasi sektor publik merupakan komponen penting untuk menciptakan akuntabilitas sektor publik. Adanya tuntutan yang semakin besar terhadap pelaksanaan akuntabilitas publik menimbulkan implikasi bagi manajemen sektor publik untuk memberikan informasi kepada publik, salah satunya adalah laporan keuangan (Mardiasmo (2002: 50). Laporan keuangan disusun untuk menyediakan informasi yang relevan mengenai posisi keuangan dan seluruh transaksi yang dilakukan oleh suatu entitas pelaporan selama satu periode pelaporan (PP No. 71 Tahun 2010). Menurut Sande (2013) terdapat 4 indikator karakteristik kualitatif laporan keuangan yaitu relevan, andal, dapat dibandingkan dan dapat dipahami.

Pernyataan Standar Akuntansi Pemerintahan (PSAP) No. 01 alinea 14, (Peraturan Pemerintah Nomor 71 Tahun 2010 ) dinyatakan bahwa komponen-komponen yang terdapat dalam satu set laporan keuangan terdiri dari laporan pelaksanaan anggaran dan laporan finansial, sehingga seluruh komponen menjadi sebagai berikut :

1. Laporan Realisasi Anggaran

2. Laporan Perubahan Saldo Anggaran Lebih

3. Neraca

4. Laporan Operasional

5. Laporan Arus Kas

6. Laporan Perubahan Ekuitas

7. Catatan atas Laporan Keuangan

\section{Aksesibilitas Laporan Keuangan ( $\left.\mathbf{X}_{2}\right)$}

Pengertian aksesibilitas dalam kamus besar bahasa Indonesia adalah hal yang dapat dijadikan akses atau hal dapat dikaitkan. Sanjaya, dkk (2014) mengemukakan bahwa aksesibilitas laporan keuangan merupakan kemudahan bagi seseorang untuk memperoleh informasi mengenai laporan keuangan. Penggunaan informasi keuangan yang efektif tergantung kepada akses public laporan keuangan yang dapat dibaca dan dipahami. Pada dasarnya masyarakat memiliki hak dasar terhadap pemerintah yaitu salah satunya hak untuk diberi infromasi yang meliputi hak untuk diberi penjelasan secara terbuka atas permasalahanpermasalahan tertentu yang menjadi perdebatan publik. laporan keuangan pemerintah merupakan hak publik yang harus diberikan oleh pemerintah, baik pusat maupun daerah. 
Dengan demikian indikator yang terdapat pada aksesibilitas laporan keuangan diantaranya (Sande (2013):

a. Keterbukaan, yaitu laporan keuangan pemerintah daerah harus dipublikasikan secara terbuka kepada pengguna laporan keuangan.

b. Kemudahan, yaitu pemerintah harus memberikan kemudahan bagi pengguna laporan keuangan dalam memperoleh informasi laporan keuangan pemerintah daerah.

c. Accessible, yaitu masyarakat dapat mengakses laporan keuangan pemerintah daerah melalui internet (website).

Menurut Riayani (2014) ada beberapa faktorfaktor yang mempengaruhi aksesibilitas laporan keuangan daerah antara lain:

a. Ketersediaan informasi laporan keuangan.

Hal yang paling utama dalam aksesibilitas laporan keuanagn daerah yaitu adanya laporan keuanagn itu sendiri. Laporan keuangan dibuat sesuai dengan kebutuhan pengguna. Adanya laporan keuangan dapat membantu pihak yang membutuhkan untuk membuat keputusan ekonomi yang bersifat financial.

b. Kualitas informasi laporan keuangan.

c. Media publikasi laporan keuangan.

\section{Akuntabilitas Pengelolaan Keuangan Daerah $\left(\mathbf{X}_{3}\right)$}

Berdasarkan PP Nomor 58 Tahun 2005 tentang Pengelolaan Keuangan Daerah, keuangan daerah adalah semua hak dan kewajiban daerah dalam rangka penyelenggaraan pemerintah daerah yang dapat dinilai dengan uang termasuk didalamnya segala bentuk kekayaan yang berhubungan dengan hak dan kewajiban daerah tersebut. Sedangkan pengelolaan keuangan daerah adalah keseluruhan kegiatan yang meliputi perencanaan, pelaksaan, penatausahaan, palaporan, pertanggungjawaban dan pengawasan keuangan daerah.

Asas umum pengelolaan keuangan daerah yang ditetapkan dalam Peraturan Menteri Dalam Negeri Nomor 13 Tahun 2006 Pasal 4 tentang Pedoman pengelolaan keuangan daerah, berisi:

a. Keuangan daerah dikelola secara tertib, taat pada Peraturan Perundang-Undangan, efektif, efisien, ekonomis, transparan dan bertanggungjawab engan memperhatikan asas keadilan, kepatuhan dan manfaat untuk masyarakat. b. Pengelolaan keuangan daerah dilaksanakan dalam suatu sitem yang terintegritasi yang diwujudkan dalam APBD yang setiap tahun ditetapkan dengan paraturan daerah.

Menurut Zeyn (2011) terdapat beberapa indikator yang terdapat dalam akuntabilitas keuangan, yaitu:

a. Perumusan rencana keuangan (Proses penganggaran), yaitu pengajuan anggaran sesuai dengan prinsip-prinsip penganggaran dan peraturan-peraturan yang berlaku, pendekatan penganggaran terpadu dilakukan dengan mengintegrasikan seluruh proses perencanaan dan penganggaran dan pengajuan anggaran telah disertai dengan kelengkapan dokumen dan bukti pendukung anggaran.

b. Pelaksanaan dan pembiayaan kegiatan, yaitu pelaksanaan belanja daerah didasarkan pada prinsip hemat, tidak mewah, efektif, efesien, dan adanya sumber pembiayaan yang jelas demi kelancaran kegiatan.

c. Melakukan evaluasi atas kinerja keuangan, yaitu kewajaran penghitungan capaian kinerja keuangan dan evaluasi pencapaian kinerja yang dilakukan menggunakan standar-standar yang telah ditetapkan.

d. Pelaksanaan pelaporan keuangan, yaitu penyelenggaraan akuntansi, laporan keuangan disampaikan kepada daerah melalui PPKD selambat-lambatnya 2 bulan setelah tahun anggaran berakhir, laporan keuangan disusun berdasarkan standar akuntansi Pemerintahan dan adanya analisis atas laporan keuangan.

Dalam pelaksanaan akuntabilitas dilingkungan instansi pemerintah, perlu diperhatikan antara lain (Halim dan Iqbal (2012):

a. Harus ada komitmen dari pimpinan dan seluruh staf instansi akuntabel.

b. Merupakan suatu system yang dapat menjamin penggunaan sumber daya "konsisten" dengan peraturan perundangan yang berlaku.

c. Dapat menunjukkan tingkat pencapaian tujuan dan sasaran yang telah ditetapkan.

d. Jujur, obyektif, transparan. 


\section{Hubungan Antar Variabel}

Hubungan Penyajian Laporan Keuangan Daerah dengan Penggunaan Informasi Keuangan Daerah

Menurut Mardiasmo (2004: 31) Pemerintah daerah selaku pengelola dana publik harus mampu menyediakan informasi keuangan yang diperlukan secara akurat, relevan, tepat waktu, dan dapat dipercaya. Menurut Sande (2013) Pemerintah daerah harus bisa menyusun laporan keuangan sesuai standar akuntansi yang diterima mum dan memenuhi karakteristik kualitatif laporan keuangan. semakin baik penyajian laporan keuangan tentu akan semakin memperjelas pelaporan keuangan pemerintah daerah karena semua transaksi keuangan dilakukan sesuai dengan peraturan yang ada dan akan disajikan dengan lengkap dan jujur dalam laporan keuangan pemerintah daerah.

\section{Hubungan Aksesibilitas Laporan Keuangan dengan Penggunaan Informasi Laporan Keuangan Daerah}

Menurut Sande (2013) pemerintah daerah harus memberikan kemudahan akses bagi para penggunaa laporan keuangan. apalah artinya menyajikan laporan keuangan dengan baik tapi tidak memberikan kemudahan akses bagi para pengguna laporan keuangan, maka usaha untuk menciptakan akuntabilitas keuangan daerah tidak akan berjalan dengan baik. Pemerintah daerah harus mampu memberikan kemudahan akses bagi para pengguna laporan keuangan, tidak hanya kepada legislative dan badan pengawasan tetapi juga kepada msyarakat yang telah memberikan kepercayaan keapda pemerintah daerah untuk mengelola dana publik.

\footnotetext{
Hubungan Akuntabilitas Pengelolaan Keuangan Daerah dengan Penggunaan Informasi Laporan Keuangan Daerah

$\begin{array}{rrrr}\text { Menurut } & \text { Sande } & \text { (2013) } & \text { akuntabilitas } \\ \text { pengelolaan } & \text { keuangan } & \text { daerah } & \text { merupakan } \\ \text { pertanggungjawaban } & \text { mengenai } & \text { integritas }\end{array}$
keuangan, pengungkapan dan ketaatan terhadap peraturan perundang-undangan. Sasaran pertanggungjawaban ini adalah laporan keuangan dan peraturan perundang-undangan yang berlaku mencakup penerimaan, penyimpanan, dan pengeluaran uang oleh instansi pemerintah.
}

\section{Kerangka Konseptual}

Berdasarkan uraian hubungan antar variabel diatas maka dapat dilihat pada gambar 2 dibawah ini:

Gambar 2

Kerangka Konseptual

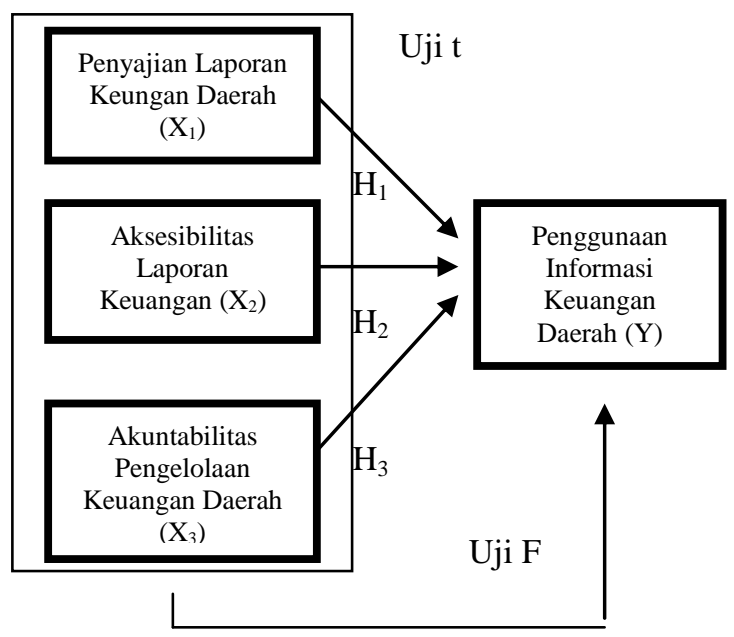

Hipotesis

Berdasarkan kerangka pemikiran diatas, maka hipotesis yang peneliti ajukan adalah sebagai berikut:

$\mathrm{H}_{1}$ : Penyajian laporan keuangan daerah berpengaruh terhadap penggunaan informasi keuangan daerah.

$\mathrm{H}_{2}$ : Aksesibilitas laporan keuangan daerah berpengaruh terhadap penggunaan informasi keuangan daerah.

$\mathrm{H}_{3}$ : Akuntabilitas pengelolaan keuangan daerah berpengaruh terhadap penggunaan informasi keuangan daerah.

$\mathrm{H}_{4}$ : Penyajian laporan keuangan daerah, aksesibilitas laporan keuangan daerah dan akuntabilitas pengelolaan keuangan daerah berpengaruh terhadap penggunaan informasi keuangan daerah.

\section{METODE PENELITIAN}

\section{Lokasi dan Objek Penelitian}

Objek penelitian ini adalah mengkaji secara dalam tentang pengaruh penyajian laporan keuangan daerah, aksesibilitas laporan keuangan daerah dan akuntabilitas pengelolaan keuangan 
daerah pada kantor DPRK Aceh Utara dan SKPK Aceh Utara.

\section{Populasi dan Sampel}

Populasi penelitian ini adalah, anggota DPRK sebanyak 45 orang dan SKPK sebanyak 34 kantor. Sampel yang dipilih berdasarkan metode purposive sampling dengan tujuan untuk mendapatkan sampel yang representative sesuai dengan kriteria yang ditentukan. Kriteria tersebut ditentukan sebagai berikut:

1. Anggota DPRK yang dipilih adalah anggota yang terlibat langsung dalam penyusunan anggaran, yaitu ketua/wakil/sektretaris masingmasing komisi DPRK. Dengan demikian jumlah sampel anggota DPRK Aceh Utara yang termasuk kedalam kriteria tersebut berjumlah 5 orang.

2. Satuan Kerja Perangkat Kabupaten (SKPK) Aceh Utara masing-masing akan diambil 2 orang sebagai responden pada bagian akuntansi atau penatausahaan keuangan disetiap masing-masing SKPK Aceh Utara. Dengan demikian jumlah sampel SKPK Aceh Utara yang termasuk kedalam kriteria tersebut berjumlah 68 orang.

\section{Jenis dan Sumber Data}

Jenis data yang digunakan dalam penelitian ini adalah data primer yaitu data yang berasal dari sumber asli atau pertama. Sumber data dalam penelitian ini adalah berasal dari responden yang penulis gunakan, yaitu anggota DPRK Aceh Utara dan SKPK Aceh Utara.

\section{Teknik Pengumpulan Data}

Penelitian ini menggunakan data primer dengan metode yang digunakan untuk memperoleh data adalah metode dokumentasi dan metode survei, dengan menggunakan teknik kuisioner yang merupakan daftar pertanyaan terstruktur yang ditujukan kepada sampel.

\section{Definisi Operasional Variabel Penelitian}

a. Penggunaan Informasi Keuangan Daerah (Y) Pembuatan laporan keuangan daerah bertujuan untuk memberi informasi keuangan yang berguna untuk pembuatan keputusan ekonomi, sosial, politik dan juga laporan akuntabilitas itu sendiri. Selain tujuan tersebut, tujuan yang lebih penting dalam pelaporan itu adalah kepuasan pengguna informasi (Ramadhani
(2014). Variabel ini diukur dengan indikator transparansi pengelolaan keuangan daerah dan akuntabilitas pengelolaan keuangan daerah (Ramadhani (2014).

b. Penyajian Laporan Keuangan Daerah $\left(\mathrm{X}_{1}\right)$ Dalam pernyataan PP Nomor 71 Tahun 2010 tentang Standar Akuntansi Pemerintah bahwa laporan keuangan merupakan laporan yang berstruktur mengenai posisi keuangan dan transaksi-transaksi yang dilakukan oleh suatu entitas pelaporan. Variabel ini diukur dengan 4 indikator yaitu: Relevan (Memiliki Manfaat umpan balik, tepat waktu, memiliki manfaat prediktif, dan lengkap), Andal (Penyajian jujur, dapat diverifikasi, netralitas), dapat dibandingkan dan dapat dipahami. (Sande (2013).

c. Aksesibilitas Laporan Keuangan $\left(\mathrm{X}_{3}\right)$

Aksesibilitas laporan keuangan merupakan kemudahan bagi seseorang untuk memperoleh informasi mengenai laporan keuangan (Sanjaya, dkk (2014). Variabel ini diukur dengan indikator terbuka dimedia massa, mudah diakses dan ketersediaan informasi (Sande (2013).

d. Akuntabilitas Pengelolaan Keuangan Daerah $\left(\mathrm{X}_{3}\right)$

Pengelolaan keuangan daerah adalah keseluruhan kegiatan yang meliputi perencanaan, pelaksaan, penatausahaan, palaporan, pertanggungjawaban dan pengawasan keuangan daerah (PP No. 58 Tahun 2005). Variabel ini diukur dengan indikator perumusan rencana, pelaksanaan dan pembiayaan kegiatan, melakukan evaluasi atas kinerja keuangan, dan pelaksanaan pelaporan keuangan. (Zeyn (2011).

\section{Teknik Analisis Data}

Teknik analisa data dalam penelitian ini menngunakan Uji Kualitas Data yang pengukurannya menggunakan Uji Validitas dan Uji Reliabilitas, metode Uji Asumsi Klasik yang pengukurannya menggunakan Uji Normalitas, Uji Autokorelasi, Uji Multikolinieritas, dan metode Analisis Regresi Linear Berganda, dengan persamaan regresi sebagai barikut:

$$
\mathrm{Y}=\mathrm{a}+\mathrm{b}_{1} \mathrm{X}_{1}+\mathrm{b}_{2} \mathrm{X}_{2}+\mathrm{b}_{3} \mathrm{X}_{3}+\mathrm{e}
$$

Keterangan: 
Daerah

$$
\mathrm{Y}=\text { Penggunaan Informasi Keuangan }
$$

$\mathrm{a}=$ Konstanta

$\mathrm{b}_{1}, \mathrm{~b}_{2}, \mathrm{~b}_{3}=$ Koefisien regresi

$\mathrm{X}_{1}=$ Penyajian Laporan Keuangan

Daerah

$\mathrm{X}_{2}=$ Aksesibilitas Laporan Keuangan

$\mathrm{X}_{3}=$ Akuntabilitas Pengelolaan Keuangan

Daerah

$\mathrm{e}=$ variabel pengganggu

\section{HASIL PENELITIAN DAN PEMBAHASAN}

\section{Uji Kualitas Data}

\section{Uji Validitas}

Uji validitas digunakan untuk membuktikan sejauh mana data yang terdapat di kuesioner dapat mengukur tingkat ke validitasan suatu kuisioner. Suatu kuisioner dikatakan valid jika pertanyaan pada kuisioner mampu untuk mengungkapkan sesuatu yang akan diukur oleh kuesioner tersebut (Ikhsan dkk.2014: 158). Kriteria pengujian adalah sebagai berikut:

1. Jika $r_{\text {hitung }} \geq r_{\text {tabel }}$ (uji 2 sisi dengan sig. 0,05) maka instrumen atau item-item pertanyaan berkolerasi signifikan terhadap skor total (dinyatakan valid).

2. Jika $r_{\text {hitung }}<r_{\text {tabel }}$ (uji 2 sisi dengan sig. 0,05) maka instrumen atau item-item pertanyaan tidak berkolerasi signifikan terhadap skor total (dinyatakan tidak valid).

Tabel 1

Hasil Uji Validitas

\begin{tabular}{|l|l|l|l|}
\hline Pernyataan & $\begin{array}{l}\text { Nilai } \\
\mathbf{r}_{\text {hitung }}\end{array}$ & $\begin{array}{l}\text { Nilai } \\
\mathbf{r}_{\text {tabel }}\end{array}$ & Kriteria \\
\hline Penyajian Laporan Keuangan Daerah $(\mathrm{X} 1)$ \\
\hline X1Q1 & 0,591 & 0,2303 & Valid \\
\hline X1Q2 & 0,497 & 0,2303 & Valid \\
\hline X1Q3 & 0,575 & 0,2303 & Valid \\
\hline X1Q4 & 0,457 & 0,2303 & Valid \\
\hline X1Q5 & 0,583 & 0,2303 & Valid \\
\hline X1Q6 & 0,524 & 0,2303 & Valid \\
\hline X1Q7 & 0,425 & 0,2303 & Valid \\
\hline X1Q8 & 0,438 & 0,2303 & Valid \\
\hline Aksesibilitas Laporan Keuangan (X2) \\
\hline X2Q1 & 0,408 & 0,2303 & Valid \\
\hline X2Q2 & 0,388 & 0,2303 & Valid \\
\hline X2Q3 & 0,644 & 0,2303 & Valid \\
\hline Akuntabilitas Pengelolaan Keuangan Daerah (X3) \\
\hline X3Q1 & 0,468 & 0,2303 & Valid \\
\hline X3Q2 & 0,627 & 0,2303 & Valid \\
\hline
\end{tabular}

\begin{tabular}{|l|l|l|l|}
\hline X3Q3 & 0,570 & 0,2303 & Valid \\
\hline X3Q4 & 0,496 & 0,2303 & Valid \\
\hline X3Q5 & 0,538 & 0,2303 & Valid \\
\hline X3Q6 & 0,524 & 0,2303 & Valid \\
\hline X3Q7 & 0,645 & 0,2303 & Valid \\
\hline X3Q8 & 0,380 & 0,2303 & Valid \\
\hline X3Q9 & 0,328 & 0,2303 & Valid \\
\hline X3Q10 & 0,326 & 0,2303 & Valid \\
\hline Penggunaan Informasi Keuangan Daerah (Y) \\
\hline Y1Q1 & 0,348 & 0,2303 & Valid \\
\hline Y1Q2 & 0,409 & 0,2303 & Valid \\
\hline Y1Q3 & 0,278 & 0,2303 & Valid \\
\hline Y1Q4 & 0,497 & 0,2303 & Valid \\
\hline Y1Q5 & 0,669 & 0,2303 & Valid \\
\hline Y1Q6 & 0,531 & 0,2303 & Valid \\
\hline Y1Q7 & 0,480 & 0,2303 & Valid \\
\hline Y1Q8 & 0,580 & 0,2303 & Valid \\
\hline Y1Q9 & 0,661 & 0,2303 & Valid \\
\hline Y1Q10 & 0,293 & 0,2303 & Valid \\
\hline Sumber: Data
\end{tabular}

Sumber: Data primer yang diolah, 2018

\section{Uji Reliabilitas}

Uji reliabilitas adalah alat untuk mengukur suatu kuesioner yang merupakan indikator dari variabel. Suatu variabel dikatakan realiabel jika memberikan nilai Cronbach Alpha >0,60.

\section{Tabel 2}

Reliabilitas Indikator Variabel Penelitian (Alpha)

\begin{tabular}{|l|l|l|l|l|}
\hline $\begin{array}{l}\text { N } \\
\text { o }\end{array}$ & $\begin{array}{l}\text { Variab } \\
\text { el }\end{array}$ & $\begin{array}{l}\text { Jumlah } \\
\text { pernyata } \\
\text { an }\end{array}$ & $\begin{array}{l}\text { Nilai } \\
\text { Alph } \\
\text { a }\end{array}$ & $\begin{array}{l}\text { Keterang } \\
\text { an }\end{array}$ \\
\hline 1 & $\begin{array}{l}\text { Penggu } \\
\text { naan } \\
\text { Informa } \\
\text { si } \\
\text { Keuang } \\
\text { an } \\
\text { Daearah } \\
\text { (Y) }\end{array}$ & 10 & 0,777 & Reliabel \\
\hline 2 & $\begin{array}{l}\text { Penyaji } \\
\text { an } \\
\text { Laporan } \\
\text { Keuang } \\
\text { an } \\
\text { Daerah } \\
\text { (X) }\end{array}$ & 8 & 0,792 & Reliabel \\
\hline 3 & $\begin{array}{l}\text { Aksesib } \\
\text { ilitas } \\
\text { Laporan } \\
\text { Keuang }\end{array}$ & 3 & 0,658 & Reliabel \\
\hline
\end{tabular}


Volume 6, Nomor 2, Agustus 2018

\begin{tabular}{|l|l|l|l|l|}
\hline & an $\left(\mathrm{X}_{2}\right)$ & & & \\
\hline 4 & $\begin{array}{l}\text { Akunta } \\
\text { bilitas }\end{array}$ & & & \\
& $\begin{array}{l}\text { Pengelo } \\
\text { laan }\end{array}$ & & & \\
& $\begin{array}{l}\text { Keuang } \\
\text { an }\end{array}$ & 10 & 0,810 & Reliabel \\
& & & \\
Daerah & & & \\
$\left(\mathrm{X}_{3}\right)$ & & & \\
\hline
\end{tabular}

Sumber: Hasil penelitian, data diolah 2018

\section{Uji Asumsi Klasik \\ Uji Normalitas}

Uji normalitas bertujuan untuk menguji apakah dalam model regresi, variabel terikat (dependet) dan variabel (independent) memiliki distribusi normal. Model regresi yang baik adalah jika distribusi data normal atau mendekati Uji Normalitas Data. Uji normalitas juga dapat dideteksi dengan analisis melalui uji kolmogrov smirnov (K-s) menggunakan pengungkapan bahwa ketentuan uji kolmogrov smirnov jika nilai signifikan lebih besar dari 0,05 maka distribusi data normal. Sebaliknya, jika nilai signifikan lebih kecil dari 0,05 maka data tersebut tidak berdistribusi normal. 


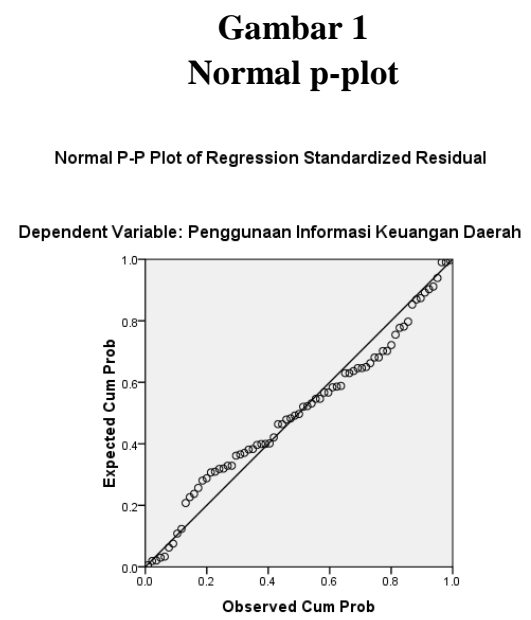

Selain uji normal probability plot, uji normalitas dalam penelitian ini juga dapat diuji dengan menggunakan uji kolmogorov-smirnov sebagai berikut:

Tabel 3

\section{Hasil Uji Normalitas}

\section{One-Sample Kolmogorov-Smirnov Test}

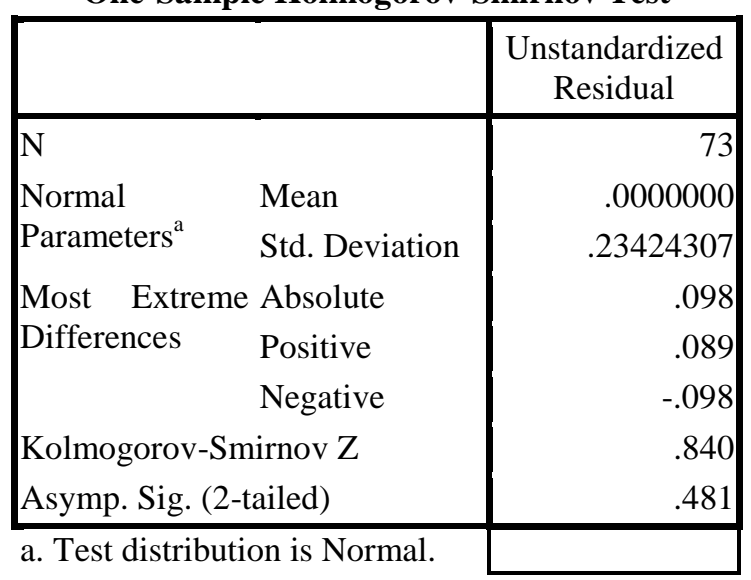

\section{Uji Multikolinearitas}

Uji multikolinieritas bertujuan untuk menguji apakah pada model regresi ditemukan adanya korelasi antar variabel independen. Jika terjadi korelasi, maka terdapat problem multikolinieritas. Pada model regresi yang baik tidak terjadi korelasi diantara variabel independen. Salah satu cara mendeteksi multikolinieritas menurut Ghozali (2005: 17) dapat dilihat dai nilai tolerance dan lawannya variance inflation factor (VIF). Nilai VIF kurang dari 10 dan nilai tolerance lebih dari 0,10 menunjukkan bahwa korelasi antar variabel independen masih bisa ditolerir atau tidak terjadi multikolinearitas (Ikhsan dkk.2014: 187).
Tabel 4

Hasil Uji Multikolinearitas

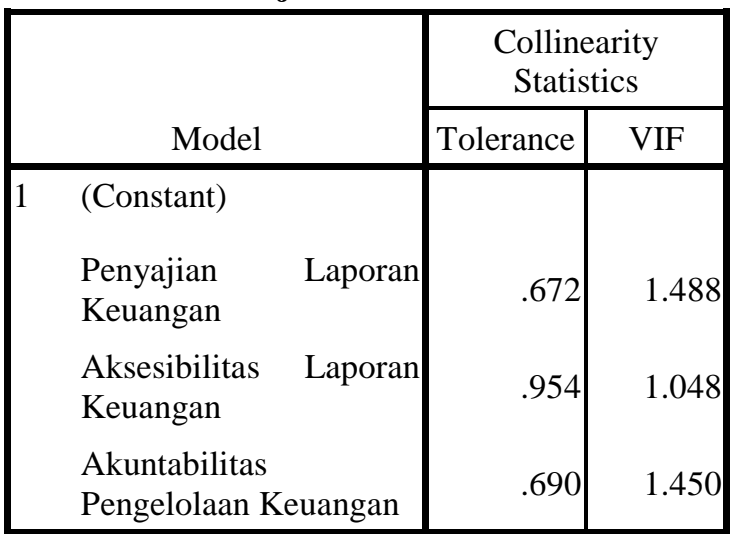

a. Dependent Variable: Penggunaan Informasi Laporan Keuangan Daerah

Sumber: Hasil penelitian, data diolah 2018

\section{Uji Autokorelasi}

Uji autokorelasi bertujuan menguji apakah dalam model regresi linier ada korelasi antara kesalahan pengganggu pada periode $t$ dengan kesalahan pengganggu pada periode $\mathrm{t}-1$ (sebelumnya). Pada penelitian ini untuk menguji ada tidaknya gejala autokorelasi menggunakan uji Durbin-Watson (DW test). Pengambilan keputusan untuk mengetahui apakah model regresi ada tidaknya terjadi autokerelasi dalam penelitian ini menggunakan uji Durbin Watson (DW) dengan ketentuan pada tabel sebagai berikut :

Pengambilan Keputusan Autokorelasi

\begin{tabular}{|l|l|}
\hline DW & Kesimpulan \\
\hline Kurang Dari 1,10 & Terdapat Autokorelasi \\
\hline Diantara 1,10-1,54 & Tanpa Kesimpulan \\
\hline Diantara 1,54-2,46 & Tidak Ada Autokorelasi \\
\hline Diantara 2,46-2,90 & Tanpa Kesimpulan \\
\hline Lebih Dari 2,90 & Terdapat Autokorelasi \\
\hline
\end{tabular}

Sumber : Winarno (2009) dalam Maulana Zikri (2016)

Tabel 5

Hasil Uji Autokorelasi

\begin{tabular}{|c|c|c|c|c|c|}
\hline $\begin{array}{l}\text { Mode } \\
1\end{array}$ & $\mathrm{R}$ & $\begin{array}{c}\mathrm{R} \\
\text { Squar } \\
\mathrm{e}\end{array}$ & $\begin{array}{c}\text { Adjuste } \\
\text { d R } \\
\text { Square }\end{array}$ & \begin{tabular}{|} 
Std. \\
Error of \\
the \\
Estimat \\
$\mathrm{e}$
\end{tabular} & $\begin{array}{l}\text { Durbin- } \\
\text { Watson }\end{array}$ \\
\hline 1 & $\begin{array}{r}769 \\
\mathrm{a}\end{array}$ & .592 & .574 & .23928 & 1.642 \\
\hline
\end{tabular}

a. Predictors: (Constant), Akuntabilitas Pengelolaan Keuangan daerah, Aksesibilitas Laporan Keuangan , Penyajian Laporan Keuangan daerah 


\begin{tabular}{|c|c|c|c|c|c|}
\hline $\begin{array}{l}\text { Mode } \\
1\end{array}$ & $\mathrm{R}$ & $\begin{array}{c}\mathrm{R} \\
\text { Squar } \\
\mathrm{e}\end{array}$ & $\begin{array}{c}\text { Adjuste } \\
\text { d R } \\
\text { Square }\end{array}$ & \begin{tabular}{|c} 
Std. \\
Error of \\
the \\
Estimat \\
$\mathrm{e}$
\end{tabular} & $\begin{array}{l}\text { Durbin- } \\
\text { Watson }\end{array}$ \\
\hline 1 & $\begin{array}{r}.769 \\
\mathrm{a}\end{array}$ & .592 & .574 & .23928 & 1.642 \\
\hline
\end{tabular}

a. Predictors: (Constant), Akuntabilitas Pengelolaan Keuangan daerah, Aksesibilitas Laporan Keuangan , Penyajian Laporan Keuangan daerah

b. Dependent Variable: Penggunaan Informasi Keuangan daerah

Sumber: Hasil penelitian, data diolah 2018

\section{Analisis Regresi Linear Berganda}

Uji regresi ini bertujuan untuk mengetahui bagaimana pengaruh variabel independen terhadap variabel dependen.

Tabel 6

Hasil Regresi Linear Berganda

\begin{tabular}{|c|c|c|c|}
\hline \multirow[b]{2}{*}{ Model } & \multicolumn{2}{|c|}{$\begin{array}{l}\text { Unstandardize } \\
\text { d Coefficients }\end{array}$} & $\begin{array}{l}\text { Standardize } \\
\text { d } \\
\text { Coefficient } \\
\text { s }\end{array}$ \\
\hline & B & $\begin{array}{l}\text { Std. } \\
\text { Error }\end{array}$ & Beta \\
\hline 1 (Constant) & .504 & .398 & \\
\hline $\begin{array}{l}\text { Penyajian Laporan } \\
\text { Keuangan daerah }\end{array}$ & .293 & .089 & .310 \\
\hline $\begin{array}{l}\text { Aksesibilitas } \\
\text { Laporan Keuangan }\end{array}$ & .113 & .051 & .174 \\
\hline $\begin{array}{l}\text { Akuntabilitas } \\
\text { Pengelolaan } \\
\text { Keuangan daerah }\end{array}$ & .495 & .092 & .496 \\
\hline
\end{tabular}

a. Dependent Variable: Penggunaan Informasi Laporan Keuangan daerah

Sumber : Hasil penelitian, data diolah 2018

Berdasarkan hasil output SPSS 16.0, dapat diperoleh $\mathrm{a}=0,504, \mathrm{~b}_{1}=0,293, \mathrm{~b}_{2}=0,113$ dan $\mathrm{b}_{3}=$ 0,495 , sehingga diperoleh persamaan regresi linear berganda sebagai berikut:

$$
Y=0,504+0,293 X_{1}+0,113 X_{2}+0,495 X_{3}+e
$$

Berdasarkan pengolahan data pada tabel 6 diatas dapat dilihat bahwa koefisien dari masingmasing variabel dan konstanta dalam penelitian ini adalah koefisien $X_{1}$ sebesar 0,293, koefisien $X_{2}$ sebesar 0,113, koefisien $X_{3}$ sebesar 0,495 dan konstanta 0,504. Dari hasil analisis menunjukkan:

1. Nilai konstanta menunjukkan nilai sebesar 0,504, artinya jika nilai variabel independen 0 (nol) maka nilai variabel dependen (Y) bernilai 0,504 .

2. Nilai variabel $X_{1}$ menunjukkan tanda positif di nilai 0,293 , artinya setiap kenaikan $1 \%$ nilai variabel $\mathrm{X}_{1}$ akan menaikan nilai variabel $\mathrm{Y}$ sebesar 0,293.

3. Nilai variabel $X_{2}$ juga menunjukkan tanda positif di nilai 0,113 , artinya setiap kenaikan $1 \%$ nilai variabel $X_{2}$ akan menaikan nilai variabel Y sebesar 0,113.

4. Nilai variabel $X_{3}$ juga menunjukkan tanda positif di nilai 0,495 , artinya setiap kenaikan $1 \%$ nilai variabel $\mathrm{X}_{3}$ akan menaikkan nilai variabel Y sebesar 0,495.

\section{Uji Hipotesis}

\section{Uji Parsial (Uji Statistik t)}

Menurut (Ikhsan at.al. 214:163 ) Uji statistik t digunakan untuk menunjukkan seberapa jauh sebuah variabel independen secara individual dalam menerangkan variasi variabel dependen.Tingkat kepercayaan untuk pengujian hipotesis adalah 95\% atau $(\alpha)=0,05(5 \%)$. Jika nilai $t_{\text {hitung }}>t_{\text {tabel }}$ dengan signifikansi 0,05 , dapat disimpulkan bahwa secara parsial variabel independen berpengaruh signifikan terhadap variabel dependen atau dapat dilakukan dengan melihat nilai signifikan di bawah 0,05.

Tabel 7

Hasil Uji t

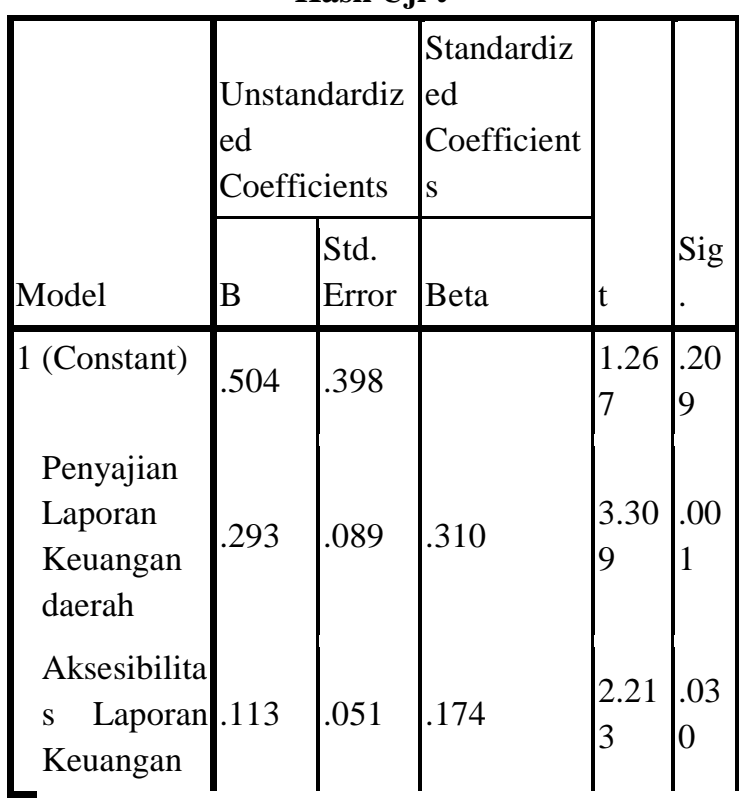




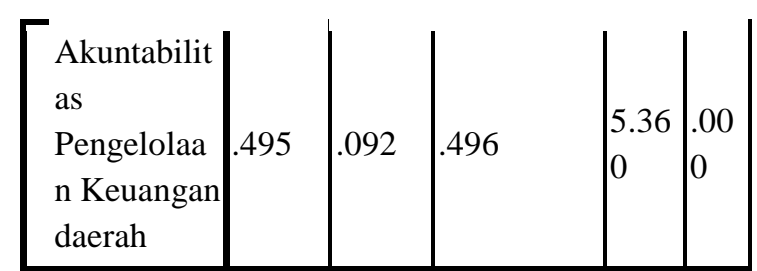

a. Dependent Variable: Penggunaan Informasi Laporan Keuangan daerah

Sumber: Hasil penelitian, data diolah 2018

Dari tabel 7 diatas dapat dilihat bahwa nilai $t_{\text {hitung }}$ untuk penyajian laporan keuangan daerah $\left(\mathrm{X}_{1}\right)$ sebesar 3.309, aksesibilitas laporan keuangan $\left(\mathrm{X}_{2}\right)$ sebesar 2.213 dan akuntabilitas pengelolaan keuangan daerah $\left(\mathrm{X}_{3}\right)$ sebesar 5.360. pengujian hipotesis dengan uji $\mathrm{t}$ dilakukan dengan membandingkan antara $t_{\text {hitung }}$ dengan $t_{\text {tabel }}$ sebagai berikut:

a. Pembuktian Hasil Pengujian Hipotesis Variabel Penyajian Laporan Keuangan Daerah $\left(\mathrm{X}_{1}\right)$

Dapat dilihat bahwa penyajian laporan keuangan daerah memiliki nilai $t_{\text {hitung }}>t_{\text {tabel }}$ yaitu $3.309>1,994$ dengan nilai signifikansi $0,01<0,05$. Hal ini menunjukkan bahwa penyajian laporan keuangan daerah $\left(\mathrm{X}_{1}\right)$ berpengaruh signifikan terhadap penggunaan informasi keuangan daerah (Y) sehingga dapat disimpulkan $\mathrm{H} 1$ diterima.

b. Pembuktian Hasil Pengujian Hipotesis Variabel Aksesibilitas Laporan Keuangan $\left(\mathrm{X}_{2}\right)$ Dapat dilihat bahwa aksesibilitas laporan keuangan memiliki nilai $\mathrm{t}_{\text {hitung }}>\mathrm{t}_{\text {tabel }}$ yaitu $2.213>1,994$ dengan nilai signifikansi $0,03<$ 0,05 . Hal ini menunjukkan bahwa aksesibilitas laporan keuangan $\left(\mathrm{X}_{2}\right)$ berpengaruh signifikan terhadap penggunaan informasi keuangan daerah (Y) sehingga dapat disimpulkan $\mathrm{H} 2$ diterima.

c. Pembuktian Hasil Pengujian Hipotesis Variabel Akuntabilitas Pengelolaan Keuangan Daerah $\left(\mathrm{X}_{3}\right)$

Dapat dilihat bahwa akuntabilitas pengelolaan keuangan daerah memiliki nilai $t_{\text {hitung }}>t_{\text {tabel }}$ yaitu 5.360 dengan nilai signifikansi $0,00<$ 0,05 . Hal ini menunjukkan bahwa akuntabilitas pengelolaan keuangan daerah $\left(\mathrm{X}_{3}\right)$ berpengaruh signifikan terhadap penggunaan informasi keuangan daerah (Y) sehingga dapat disimpulkan bahwa $\mathrm{H} 3$ diterima.

\section{Uji Simultan (Uji Statistik F)}

Menurut (Ikhsan et.al. 214:163) Uji F digunakan untuk mengetahui apakah variabelvariabel independen secara simultan berpengaruh signifikan terhadap variabel dependen. Derajat kepercayaan yang digunakan adalah 0,05. Apabila nilai $\mathrm{F}$ hasil perhitungan lebih besar dari pada nilai F menurut tabel maka hipotesis alternatif, yang menyatakan bahwa semua variabel independen secara simultan berpengaruh signifikan terhadap variabel dependen.

Tabel 8

Hasil Uji F

\begin{tabular}{|l|c|c|c|c|c|}
\hline & $\begin{array}{c}\text { Sum } \\
\text { of } \\
\text { Square } \\
\text { s }\end{array}$ & df & $\begin{array}{c}\text { Mean } \\
\text { Square }\end{array}$ & F & Sig. \\
\hline Model & 3.730 & 3 & 1.910 & 33.360 & $.000^{\mathrm{a}}$ \\
\hline $\begin{array}{l}\text { 1 Regress } \\
\text { ion } \\
\text { Residua } \\
1\end{array}$ & 3.951 & 69 & .057 & & \\
Total & 9.681 & 72 & & & \\
\hline
\end{tabular}

a. Predictors: (Constant), Akuntabilitas Pengelolaan Keuangan daerah , Aksesibilitas Laporan Keuangan, Penyajian Laporan Keuangan daerah

b. Dependent Variable: Penggunaan Informasi Laporan Keuangan daerah

Sumber: Hasil penelitian, data diolah 2018

Hasil uji hipotesis 4 dapat dilihat pada tabel 8 , nilai $\mathrm{F}_{\text {hitung }}>\mathrm{F}_{\text {tabel }}$ yaitu $33.360>2,74$ dengan tingkat signifikansi $0,00<0,05$. Hal ini berarti secara simultan menerima $\mathrm{H} 4$ bahwa penyajian laporan keuangan daerah, aksesibilitas laporan keuangan dan akuntabilitas pengelolaan keuangan daerah berpengaruh signifikan terhadap penggunaan informasi keuangan daerah.

\section{Koefisien Determinasi $\left(\mathbf{R}^{2}\right)$}

Koefisien determinasi (R2) pada intinya mengukur seberapa jauh kemampuan model dalam menerangkan variasi variabel dependen (Y), sedangkan sisanya di jelaskan oleh variabel lain di luar model. 
Tabel 9

Hasil Koefisien determinasi (R-Square atau $\mathbf{R}^{\mathbf{2}}$ )

\begin{tabular}{|l|r|r|r|r|r|}
\hline $\begin{array}{l}\text { Mode } \\
1\end{array}$ & $\mathrm{R}$ & $\begin{array}{c}\text { Squar } \\
\mathrm{e}\end{array}$ & $\begin{array}{c}\text { Adjuste } \\
\mathrm{d} \mathrm{R} \\
\text { Square }\end{array}$ & $\begin{array}{c}\text { Std. } \\
\text { Error of } \\
\text { the } \\
\text { Estimat } \\
\mathrm{e}\end{array}$ & $\begin{array}{l}\text { Durbin- } \\
\text { Watson }\end{array}$ \\
\hline 1 & $\begin{array}{r}.769 \\
\mathrm{a}\end{array}$ & .592 & .574 & .23928 & 1.642 \\
\hline
\end{tabular}

a. Predictors: (Constant), Akuntabilitas Pengelolaan Keuangan daerah, Aksesibilitas Laporan Keuangan , Penyajian Laporan Keuangan daerah

b. Dependent Variable: Penggunaan Informasi Keuangan daerah

Sumber: Hasil penelitian, data diolah 2018

Berdasarkan hasil pengujian diatas menunjukkan besarnya koefisien korelasi (R), koefisien determinasi ( $\mathrm{R}$ square), dan koefisien determinasi yang disesuaikan (Adjusted $R$ Square). Berdasarkan tabel model summary di atas diperoleh bahwa nilai koefisien korelasi (R) sebesar 0,769. Ini menunjukkan bahwa variabel penyajian laporan keuangan daerah, aksesibilitas laporan keuangan, dan akuntabilitas pengelolaan keuangan daerah terhadap penggunaan infromasi keuangan daerah mempunyai hubungan yang kuat. Hasil pada tabel di atas juga menunjukkan bahwa nilai koefisien determinasi ( $R$ Square) sebesar 0,592 dan nilai koefisien determinasi yang sudah disesuaikan (Adjusted $R$ Square) adalah 0,574.

Hal ini berarti $57.4 \%$ variasi dari penggunaan infromasi keuangan daerah dapat dijelaskan oleh variasi independen (penyajian laporan keuangan daerah, aksesibilitas laporan keuangan dan akuntabilitas pengelolaan keuangan daerah). Sedangkan sisanya $42,6 \% \quad(100 \%-57,4 \%)$ dijelaskan oleh variabel lain yang tidak disertakan dalam penelitian ini.

\section{Hasil Pembahasan}

\section{Pengaruh Penyajian Laporan Keuangan Daerah} terhadap Penggunaan Informasi keuangan Daerah

Berdasarkan hasil penelitian maka penyajian laporan keuangan daerah berpangaruh terhadap penggunaan informasi keuangan daerah karena dengan terwujudnya laporan keuangan yang baik dan berstruktur yang lakukan oleh Pemerintah Daerah maka akan baik pula bagi penggunaan informasi keuangan daerah. Penyajian laporan keuangan yang berkualitas adalah laporan yang diharapkan bagi semua pengguna laporan keuangan daerah, untuk dapat memenuhi kualitas yang tersebut adalah diperlukannya karakteristik kualitatif laporan keuangan diantara yaitu relevan, andal, dapat dibandingkan dan dapat dipahami.

\section{Pengaruh Aksesibilitas Laporan Keuangan terhadap Penggunaan Informasi keuangan Daerah}

Berdasarkan hasil penelitan maka aksesibilitas laporan keuangan berpangaruh terhadap penggunaan informasi keuangan daerah karena Tingginya aksesibilitas laporan keuangan maka akan menigkatkan penggunaan laporan keuangan, artinya bahwa penggunaan informasi keuangan daerah akan berjalan dengan baik apabila didukung oleh akses laporan keuangan yang akuntabel dan transparan.

\section{Pengaruh Akuntabilitas Pengelolaan Keuangan Daerah terhadap Penggunaan Informasi keuangan Daerah}

Berdasarkan hasil penelitian maka akuntabilitas pengelolaan keuangan daerah berpengaruh terhadap penggunaan informasi keuangan daerah karena Semakin akuntabel pengelolaan keuangan daerah, maka semakin baik pula penggunaan informasi keuangan daerah, karena akuntabilitas adalah pertanggungjawaban yang harus pemerintah lakukan dalam memenuhi kepuasan para pengguna keuangan daerah. Pertanggungjawaban pengelolaan keuangan daerah merupakn sesuatu yang penting untuk mendapatkan kepastian mengenai keberhasilan atau ketepatan suatu kegiatan pengelolaan keuangan dalam mencapai tujuan dan sasaran yang telah ditetapkan.

Pengaruh Penyajian Laporan Keuangan Daerah, Aksesibilitas Laporan Keuangan dan Akuntabilitas Pengelolaan Keuangan Daerah terhadap Penggunaan Informasi keuangan Daerah

Berdasarkan hasil penelitian maka penyajian Penyajian Laporan Keuangan Daerah, Aksesibilitas Laporan Keuangan dan Akuntabilitas Pengelolaan Keuangan Daerah terhadap Penggunaan Informasi keuangan Daerah karena Akuntabilitas merupakan pertanggunjawaban pemerintah dalam mengelola keuangan daerah. Dengan pemerintah mengelola keuangan daerah dengan akuntabel dan transparan, itu akan berdampak bagi baik bagi penggeunaan keuangan daerah. 


\section{KESIMPULAN DAN SARAN}

\section{Kesimpulan}

Berdasarkan dari hasil penelitian yang diperoleh dalam penelitian ini adalah sebagai berikut:

1. Penyajian laporan keuangan daerah memiliki nilai $t_{\text {hitung }}>t_{\text {tabel }}$ yaitu $3.309>1,994$ dengan nilai signifikansi $0,01<0,05$, sehingga penyajian laporan keuangan daerah berpengaruh signifikan terhadap penggunaan informasi keuangan daerah. Hal ini membuktikan bahwa penyajian laporan keuangan daerah berpengaruh terhadap penggunaan informasi keuangan daerah.

2. Aksesibilitas laporan keuangan memiliki nilai $t_{\text {hitung }}>t_{\text {tabel }}$ yaitu $2.213>1,994$ dengan nilai signifikansi $0,03<0,05$, sehingga aksesibilitas laporan keuangan berpengaruh signifikan terhadap penggunaan informasi keuangan daerah. Hal ini membuktikan bahwa aksesibilitas laporan keuangan berpengaruh terhadap penggunaan informasi keuangan daerah.

3. Akuntabilitas pengelolaan keuangan daerah memiliki nilai $t_{\text {hitung }}>t_{\text {tabel }}$ yaitu 5.360 dengan nilai signifikansi $0,00<0,05$. Sehingga akuntabilitas pengelolaan keuangan daerah berpengaruh signifikan terhadap penggunaan informasi keuangan daerah. Hal ini membuktikan bahwa akuntabilitas pengelolaan keuangan daerah berpengaruh terhadap penggunaan informasi keuangan daerah.

4. Penyajian laporan keuangan daerah, aksesibilitas laporan keuangan dan akuntabilitas pengelolaan keuangan daerah memiliki nilai $F_{\text {hitung }}>F_{\text {tabel }}$ yaitu $33.360>2,74$ dengan tingkat signifikansi $0,00<0,05$. Hal ini berarti secara simultan bahwa penyajian laporan keuangan daerah, aksesibilitas laporan keuangan dan akuntabilitas pengelolaan keuangan daerah berpengaruh signifikan terhadap penggunaan informasi keuangan daerah.

\section{Saran}

Berdasarkan kesimpulan yang ada, penulis memberikan beberapa saran sebagai berikut:

1. Untuk penelitian selanjutnya dapat menambahkan atau memperluas populasi maupun sampel penelitian. Terutama untuk sampel yang mewakili masyarakat dan juga yang mewakili pihak Anggota Dewan.
2. Untuk penelitian selanjutnya, dapat dilakukan dengan berbagai macam metode pengambilan data, seperti wawancara langsung, metode survey lapangan, dan lain-lain.

3. Penelitian ini hanya meninjau penggunaan informasi keuangan daerah Kabupaten Aceh Utara dari aspek laporan keuangan, aksesibilitas laporan keuangan dan akuntabilitas saja, untuk penelitian selanjutnya dapat pula ditambahkan atau diganti variabel lainnya seperti transparansi, sumber daya manusia dan lainnya yang mampu membuktikan praktik penggunaan informasi keuangan daerah dan perwujudan akuntabilitasnya oleh pemerintah daerah.

\section{DAFTAR PUSTAKA}

Bandariy, Himmah (2011). Pengaruh Penyajian Laporan Keuangan Daerah dan Aksesibilitas Laporan Keuangan Terhadap Penggunaan Informasi Keuangan Daerah (Studi Pada Kabupaten Eks Karesidenan Banyumas). Skripsi Akuntansi. Universitas Diponerogo. Semarang.

Fauziah, Miftahul Reza. (2017). Pengaruh Penyajian dan Aksesibilitas Laporan Keuangan Daerah terhadap Akuntabilitas Pengelolaan Keuangan Daerah. Jurnal Ilmu dan Riset Akuntansi, Vol 6, Hal 3-7

Ghozali, Imam. (2005). Aplikasi Analisis Multivariate dengan program SPSS. Universitas Diponogoro. Semarang.

Governmental Accounting Standards Board (1999).

Tujuan dan Fungsi Laporan Keuangan Sektor Publik.

Halim, Abdul dan Iqbal, Muhammad. (2010). Seri

Bunga Rampai Manajemen

Keuangan Daerah: Pengelolaan

Keuangan Daerah. UPP STIM YKPN, Yogyakarta.

Hehanussa, Salomi J. (2015). Pengaruh Penyajian Laporan Keuangan Daerah Dan Aksesibilitas Laporan Keuangan Daerah Terhadap Transparansi Dan Akuntabilitas Pengelolaan Keuangan Daerah Kota Ambon. 2nd Cbam, Vol.2, No 1. Hal. 82 
http://bandaaceh.bpk.go.id. Opini untuk LKPD Kabupaten Aceh Utara TA 2014 dan 2016. Harian BPK RI perwakilan Provinsi Aceh 5 November 2017. Diunduh 10 November 2017.

http://acehutara.go.id

http://riayanikusuma.wordpress.com/2014/04/30/la poran-keuanagn-transparanmelindungi-investor-danmeningkatkan-kualitas-pasar/. Laporan Keuangan Daerah. diunduh tanggal 5 November 2017.

Mahmudi. (2010). Analisis Laporan Keuangan Pemerintah Daerah. Ed. II; Sekolah Tinggi Ilmu Manajemen YKPN, Yogyakarta.

Mardiasmo. (2002). Akuntansi Sektor Publik. Andi, Yogyakarta

, (2002) Pengawasan, Pengendalian dan Pemeriksaan Kinerja Pemerintah Daerah dalam Pelaksanaan Otonomi Daerah. Andi, Yogyakarta.

(2004). Otonomi dan Manajemen Keuangan Daerah. . Andi, Yogyakarta.

Mulia, Waode alnur. (2016). Pengaruh Penyajian Laporan Keuangan Daerah dan Aksesibilitas Laporan Keuangan terhadap Penggunaan Informasi Keuangan Daerah. Skripsi Akuntansi. UIN Alauddin. Makassar.

Mulyana, Budi. (2006). Pengaruh Penyajian

Neraca Daerah dan Aksesibilitas Laporan Keuangan terhadap Transparansi dan Akuntabilitas Pengelolaan Keuangan Daerah. Jurnal Akuntansi Pemerintahan. Vol.2, No. 1, Hal 1-21.

Modo, Saerang dan Agus Tony Pupotro. Analisis

Faktor-Faktor yang Mempengaruhi

Kualitas Informasi Laporan

keuangan Daerah Kabupaten

Kepulauan Talaud. Jurnal Akuntansi. Hal 17-19.

Nordiawan, Deddi. (2010). Akuntansi SektorPublik. Salemba Empat, Jakarta.

Ramadhani, Taufik dan Lila Anggraini. (2014).

Pengaruh Penyajian Laporan

Keuangan Daerah Dan Aksesibilitas

Terhadap Penggunaan Informasi Keuangan Daerah (Study Pada
Provinsi Riau). Jom Fekon, Vol. 1, No. 2, Hal 1-15

Republik Indonesia. (2004). Peraturan Pemerintah RI Nomor 24 Tahun 2005. Tentang Standar Akuntansi Pemerintah.

(2004). Undang-Undang Nomor 33 Tahun 2004. Tentang Perimbangan antara Keuangan Pemerintah Pusat dan Pemerintah Daerah.

. (2005). Peraturan Pemerintah Nomor 58 Tahun 2005. Tentang Pengelolaan Keuangan Daerah.

(2006). Peraturan Menteri Dalam Negeri Nomor 13 Tahun 2006.

Tentang Pedoman Pengelolaan Keuangan Daerah.

. (2008). Qanun Kabupaten Aceh Utara Nomor 6 Tahun 2008. Tentang Pokok-Pokok Pengelolaan Keuangan Daerah.

(2008). Peraturan Menteri Dalam Negeri Nomor 4 Tahun 2008.

Tentang Pedoman Pelaksanaan Review atas Laporan Keuangan Pemerintah Daerah.

(2008). Undang-Undang Nomor 14 Tahun 2008. Tentang Keterbukaan Informasi Publik.

. (2010). Peraturan Pemerintah Nomor 71 Tahun 2010. Tentang Standar Akuntansi Pemerintah.

. (2014). Undang-Undang Nomor 23 Tahun 2014. Tentang Pemerintah Daerah.

Rohman, Abdul. (2009). Aksesibilitas, Penyajian dan Penggunaan Informasi Keuangan Daerah (Studi pada Kota dan Kabupaten Tegal). Jurnal Akuntansi. Tahun XIII. No.03, Hal 252-264

Sande, Peggy. (2013). Pengaruh Penyajian Laporan Keuangan dan Aksesibilitas Laporan Keuangan Terhadap Akuntabilitas Pengelolaan Keuangan Daerah. Jurnal Akuntansi, Vol. 1. No. 1. Hal 11-16

Sanjaya, Sujana dan Ni Luh Gede Erni Sulindawati. (2014). Pengaruh Penyajian Laporan Keuangan Daerah Dan Aksesibilitas Terhadap 
Penggunaan Informasi Keuangan Daerah (Studi Pada satuan Kerja Perangkat Daerah Kabupaten Buleleng). e-Journal Vol. 2, No. 1. Hal. 1-12

Saputra, Ardi Rahmawan. (2012). Kajian Penggunaan Informasi Keuangan Daerah. Accounting Analysis Journal. Vol 1. No. 2, Hal. 1-6

Sari, Embun Widya. (2017). Pengaruh Pengendalian Intern, Penyajian Laporan Keuangan, Aksesibilitas Laporan Keuangan dan Gaya Kepemimpinan terhadap Transparansi dan Akuntabilitas Pengelolaan Keuangan. JOM Fekom, Vol 4 No. 1, Hal 571-578

Sugiyono. (2011). Metode Penelitian Kuantitatif, Kualitatif, dan Kombinasi (Mix Methods). Cet. 1. Bandung: Alfabeta.

Sukmanigrum. (2012). Analisis Faktor-Faktor yang Mempengaruhi Kualitas Informasi Laporan Keuangan Daerah. Skrikpsi Akuntansi. Universitas Diponegoro. Semarang.

Wilopo, Indra Agung. (2017). Analisis Faktor-

Faktor yang Mempengaruhi Akuntabilitas dan Transparansi Informasi Keuangan Daerah melalui Website di Yogyakarta. Vol VII, No 1, Hal. 61-78

Zeyn, Elvira (2011), Pengaruh Penerapan Good Governance dan Standar Akuntansi Pemerintahan terhadap Akuntabilitas Keuangan, Vol 10, No 1, Hal 58. 